\title{
MNCs and the Transfer and Diffusion of 'Soft' Technologies: Issues for Central and Eastern Europe*
}

\author{
Chris Warhurst $^{* *}$
}

Dieser Artikel untersucht die Übertragung innovativer 'weicher' Technologien durch direkte Fremdinvestition seitens multinationaler Konzerne und ihre nachfolgende Verbreitung in einheimische Firmen. Unter Nutzung dieser in den entwickelten kapitalistischen Ökonomien bereits gesammelten Erfahrungen wirft er ein Schlaglicht auf Aspekte der Übertragung und Verbreitung innerhalb restrukturierender Länder Mittel- und Osteuropas. Er besagt, daß die Strategien multinationaler Konzerne, die Regierungspolitik im Gast- und Herkunftsland, die nationalen Geschäftssysteme, die Eigenart einheimischer Firmen und die Art des Wissens entscheidende Faktoren für das Verständnis der Übertragungsprozesse dieser 'weichen' Technologien auf mittel- und osteuropäische Länder sind.

This article examines the transfer of innovative 'soft' technologies by multinational companies (MNCs) through foreign direct investment and the diffusion of those technologies by those MNCs into indigenous firms (IFs). By drawing upon the experience of such transfer and diffusion in the developed capitalist economies, it highlights issues germane to that transfer and diffusion within restructuring Central and Eastern European (CEE) countries. It suggests that MNC strategies, host country and country of origin government policies characteristic of national business systems, the capabilites of IFs and the nature of knowledge are key factors in understanding the transfer of soft technologies to CEE.

\footnotetext{
* manuscript received: 16.04.1999, accepted: 28.04.1999;

** Chris Warhurst, born 1964, gained his doctorate through an analysis of the transformation of communal socialist industry. He is Lecturer in Organisational Behaviour in the Department of Management Studies at the University of Glasgow. His research and teaching interests focus on management and labour issues in the international economy. The author would like to thank Lee Murray and David Roe for their help in translating material.
} 


\section{Introduction}

With the collapse of the Soviet Union, economic and organisational restructuring became an imperative within the former socialist states of Central and Eastern Europe (CEE). It was argued at the time that with this restructuring and hefty Western capital investment, these former state socialist countries had the potential to 'become the tigers of Europe' (Kirkland, 1989: 48). Within this restructuring much was made of the need to jettison existing management techniques, believing that the legacy of state socialism was 'the absence of skilled managerial talent' (Hertz, 1991: 60) and that this absence would prove to be increasingly problematic as 'the role of enterprise managers ha[d] probably changed forever' (Sadove, 1989: 149). Previous management was thus negated as a bad habit to be broken or a bad experience to be forgotten. ${ }^{1}$

With the aid of management consultants, the key to economic and organisational restructuring, and managerial learning, was privatisation. Rather quickly these demands for privatisation transmuted into calls for foreign direct investment (FDI) from Western multinational companies (MNCs), both greenfield as well as brownfield. The likelihood of FDI seemed particularly good in the early 1990s. In a report prepared for the European Commission in 1991-1992 based on discussions with 174 of the Top 500 companies in Europe, Japan and the USA, over half were considering investing in CEE, with the market potential of the region being the greatest incentive (Bunt, 1992). The view of the senior management of these investing MNCs was that the workforce of CEE countries was skilled and educated, and its potential could be 'fairly easily realised given training and the incentive' (p.3). However the same was not true, these senior managers believed, of management in CEE - but then this was perceived by them as a common problem with indigenous management of all 'lagging regions'. With FDI, everyone then could be a winner: MNCs could access new markets, domestic consumers would gain new goods and services, local workers would be retrained and indigenous management could learn new management techniques.

This 'everyone could be a winner' approach was however tempered by the mid$1990 \mathrm{~s}$ by analysis of the investment patterns of MNCs and the results of emerging empirical research in the region. With regard to investment patterns, although initial expectations about the volume of FDI were confounded, FDI in CEE has increased during the 1990s, rising to four per cent of the world-wide

\footnotetext{
${ }^{1}$ Of course such claims ignored the entrepreneurial skills of state socialist management developed through horizontal and vertical negotiations with other enterprises and state officials respectively during the era of the planned economy, as well as these managers experience of international production patterns through the, admittedly limited, trade of large state enterprises with both the 'first' and 'third' worlds during the same era. However, exploration of the myths of state socialist management requires another article.
} 
total by the end of 1995 (Pye, 1998). Nevertheless, by the early 1990s, it was becoming clear that manufacturing FDI entering CEE was not new but that being diverted away from other peripheral regions, for example from Asian and Latin America. Even so, these regions continued to receive more FDI than CEE (Financial Times, 1992). Moreover, until 1997, particular countries in CEE Hungary and the Czech Republic - attracted most MNC FDI (Business Central Europe Online, 1999). A fear began to emerge that CEE represented a region of cheap production with skilled but nonetheless low wage labour for investing MNCs. From the results of empirical research, there was some evidence of an emerging dislocation between local and global ${ }^{2}$ economies either because the expected FDI was not materialising or because the indigenous firms (IFs) of CEE were not engaging international production through linkages with those MNCs that were investing. As a result, the 'vast majority' of IFs in Poland, for example, were becoming 'members of the flea market rather than the free market' argued Rainnie and Hardy (1996: 55-56), compounding the economic peripherality of CEE countries prior to 1989. Not surprisingly, questions began to be asked about where restructured CEE countries fit into the structure of the capitalist global economy with regard to $\mathrm{MNCs}$ ' international production strategies and host country national economic characteristics and policies.

This article examines the effects and process of the transfer and diffusion of innovative soft technologies into host countries through the FDI. Etymologically, a 'technique' - often involving skill or artistry - is a relational and deliberate form of execution: 'Techniques [are] ways of carrying out conscious activities which can potentially be understood by others. In essence, they are social - capable, by definition, of being communicated, shared and imitated' (Friedman, 1990: 201). A technology is a collection of techniques: Usually, technology refers only to machinery and tools - what might be termed 'hard' technology. However, as Friedman notes, this conceptualisation is too narrow. ${ }^{3}$ By the term 'soft' technologies used in this article, we mean managerial techniques concerned with the utilisation of labour in production by management. In respect to this article, these techniques involve the transfer and diffusion of managerial 'know-how' about innovative working practices and human resource management. There are thus two specific concerns here, firstly the transfer of innovative soft technologies into host countries by MNCs through FDI and, secondly, the diffusion of these soft technologies from these MNCs to

\footnotetext{
${ }^{2}$ The term 'global' is used loosely. Ontological and epistemological critiques of it can be found in Warhurst, Nickson and Shaw (1998) and Martin (1998).

${ }^{3}$ Within this article a distinction is being made here between the 'soft' technologies and 'hard' technologies. Elsewhere the same distinction is made with reference to 'social' technologies and 'physical' technologies (Chen, 1996). This distinction can be useful if it enables an inclusion of the social/soft as well as the physical/hard into a conceptualisation of technology, although it must be said that both are interrelated if still distinct.
} 
IFs through supply chain relations. By drawing upon experiences from outside the former state socialist countries of CEE, the article highlights the issues arising from these experiences for these former state socialist countries.

There is extensive evidence on the role of MNCs in the international diffusion of 'hard' technology, both within MNCs and between MNCs and other firms, and within the industrialised world and between the developed and developing capitalist states (Archibugi and Michie, 1997; Chen, 1996; Dunning, 1993; Pavitt and Patel, 1988). Once neglected, there is also now an emerging but already substantial literature on the transfer of 'soft' technologies within the capitalist world, especially in recent years associated with 'Japanisation' (Oliver and Wilkinson, 1992, Elger and Smith 1994; Darby, 1997). There is an emerging literature on the transfer of 'hard' technology between the West and the former state socialist states of CEE (Dyker, 1997). However there is little empirical research on the transfer of 'soft technologies' between the West and the former state socialist countries. Of concern here is the extent to which innovative soft technologies can be and are introduced by MNCs into host countries in CEE and then can be and are diffused between MNCs and IFs. A number of factors come into play here; MNCs' strategies, the national institutional systems of host countries, the capacity of IFs, and the idiosyncrasies of knowledge. Given that the main focus of this discussion is the transfer of soft technologies across borders, examination of the national institutional systems of host countries is particularly germane. International business and management research has traditionally developed within an economic framework (for example, Casson, 1990). The approach here is sociological, whilst recognising that the issues have an economic as well as a sociological dimension (Buckley, 1992).

The rest of this article is divided into four sections: the following section indicates the issues pertinent to the examination of the transfer and diffusion of soft technologies in relation to MNCs and IFs, the second section then outlines the two ideal types of models for this transfer and diffusion; the third section then highlights the interests and factors which influence the applicability of these two models, finally the conclusion suggests why the examination of this transfer is important, particularly in the context of the development of the economies of CEE.

\section{Issues}

The main focus here is the relationship between MNCs and IFs in different national institutional systems. MNCs play a central role in the international transfer of technology through transfers within their own organisation (intrafirm) and through inter-organisational relationships (inter-firm with suppliers, sub-contractors, etc.) (Archibugi and Michie, 1997). Whilst there is much debate about whether or not in an era of 'globalisation' MNCs are attempting to 
standardise their organisational structures and practices in operations around the world (see, for example, Warhurst, Nickson and Shaw, 1998), there is evidence that MNCs are more sensitive to local conditions with regard to the management of labour than other organisational areas (Ferner, 1997). At issue is the diffusion of innovations in the management of labour, both specific human resource management practices (selection procedures, training, payments systems, industrial relations practices, contractual arrangements) and more generally in new working practices (for example, functional flexibility and teamworking).

If the former state socialist countries are to attain an international competitiveness, it must be recognised that such competitiveness relies on advances in both forms of technologies - hard and soft, and that advances in the latter must occur at intra-firm and inter-firm levels, as it does for capitalist countries (Hoffman, 1986; 1990). Recent research has stressed the importance of links between MNCs and IFs for innovation, both technological and managerial. Kimura, for example, in discussing Japanese FDI, comments that '[where Japanese firms] integrate their production activities with local suppliers [they] effectively train not only their own employees but also those of suppliers through the technical assistance that they provide. Such linkages between Japanese affiliates and local suppliers provide a conduit for technology and other managerial resource transfers. And in addition to these direct transfers, there may be demonstration effects of Japanese management practices available to local vendors' (Kimura, 1997: 32). The importance of management techniques, tacit skills and informal as well as formal organisational learning for increasing overall $x$-efficiency, and for the effective use of new technology specifically has been a central theme of management research at least since the early 1980s (Argyris, 1992; Senge, 1990; Liebenstein, 1978; etc.).

\section{Models of Transfer}

The relationship between MNCs and IFs may be conceptualised in terms of two 'ideal type' models. As ideal types, it must be emphasised that these are conceptualisations perhaps best regarded as polar positions along a continuum of possibilities. It might be, for example, that 'hybrid' forms emerge as MNCs transfer into the host country intra-firm innovative soft technologies as 'best practice' but do not engage a local supply chain such that no inter-firm diffusion occurs and the MNC remains a 'cathedral of capitalism'.

\section{The Best Practice Model}

According to the first model, MNCs act as exemplars of innovative best practice, both in hard and soft technologies. This exemplification may be 'genuine' or ideological, in providing a justification for policies which management wished to pursue for other reasons (Taylor, Elger and Fairbrother, 
1994), but exemplification may be real and significant. This best practice may be disseminated in three main ways.

First, dissemination may occur through the supply chain, where the MNC establishes quality standards which need to be met when components are supplied by indigenous manufacturers (Macbeth, 1995). Suppliers may be required to develop their production methods to meet the required MNC quality standards, although it is an empirical question as to how far customers concern themselves with production methods as well as the products themselves. That is, product innovation may occur for IFs but there is no innovation in the process of production within IFs so that no change occurs in their working practices or human resource management. Supplier quality standards have been a primary concern in the approach towards IFs adopted by Japanese MNCs investing in manufacturing in the UK (Oliver and Wilkinson, 1992). Although government polices concerned with increasing the proportion of locally sourced components may be based primarily on economic considerations, especially employment generation, participating in MNC supply chains also provides major learning opportunities. Such opportunities are especially valuable where multinationals operate on 'obligational contractual relationships' rather than 'arms length contractual relations' (Sako, 1992), since they provide a channel for a broader transfer of knowledge.

Second, dissemination may also occur through the creation of joint ventures between MNCs and IFs, for example for the production of specialised components, as with the network of suppliers associated with VW-Skoda in the Czech Republic (Martin, 1998). Such joint ventures are especially important where IFs retain comparable wholly owned enterprises, for whom the newly learned techniques may be relevant. For the IF the learning opportunities offered may be the main value of the joint venture, as in the Rover-Honda joint venture in the UK. However, the incoming MNC may be anxious about the seepage of expertise to other enterprises, especially in poorly regulated economies, desiring instead to maintain firm specific advantages.

Thirdly dissemination may occur through providing benchmarks for performance by IFs. Such benchmarks may be disseminated through formal sectoral organisations (such as the Electronics Forum in Scotland), through formal state sponsored economic development activities and through informal networks and associations. In the 1970s, British manufactured colour televisions were of an inferior quality and involved less efficient manufacture (soft technology) than those produced by Japanese firms. As a result increasing numbers of these television sets were being imported into the UK. The Government believed that British firms could learn from their Japanese counterparts and the Department of Industry encouraged Japanese firms to locate production in the UK so long as these firms provided 'demonstration 
effects' (Cawson, 1993). ${ }^{4}$ The relevance of such bench-marking depends upon the level of comparability between MNCs and IFs, for example in capital vintage.

\section{The Cathedrals of Capitalism Model}

According to the second model, MNCs invest in high levels of production technology as part of a global strategy: production as well as marketing is organised internationally (Ohmae, 1995). Such firms, whilst transferring best practice soft technology into the host country, develop largely in isolation from domestic enterprises so that diffusion does not occur to IFs. High value added components, for example engines in motor vehicles, may be imported. MNCs contribute significantly to national economies through favourable capital flows, local taxation and direct expenditures on wages; and for these reasons MNC investment is attractive to national governments. However, the result may be the 'maquiladora' syndrome, the creation of an internationally oriented industrial enclave as in Northern Mexico (Ellingstad, 1997). In extreme cases, FDI by MNCs merely provides a production platform for the importation of supplies, components and raw materials and the exportation to markets outside the host country of finished goods, and may not even involve the transfer into the host country of innovative best practice. Even in less extreme cases, the multiplier effects are limited. There is little integration into the national economy. There is only limited transfer of innovation and learning opportunities for IFs are few. The result is the creation of a dual economy in which MNCs may represent 'cathedrals of capitalism'. The effect of the creation of such international 'beach heads' within the national economy is uneven development and social and economic fragmentation.

After reviewing a range of United Nations commissioned research about FDI, there is strong evidence that MNCs from the developed capitalist countries tend to establish few links with IFs in developing countries (Balasubramanyam, 1994). Research on the 'new international division of labour' has also shown that investment in developing countries has characteristically followed the second model rather than the first (Frobel et al., 1980; Buckley, 1995). Where MNCs have invested because of access to raw materials or cheap energy supplies, the incentive to operate independently of the indigenous economy are especially strong: production technology, markets and technical expertise are foreign. Similarly, firms motivated to internationalise by prospective low labour costs alone may have limited motivations for local involvement. The perceived

\footnotetext{
${ }^{4}$ One result of this Government strategy was that by also insisting that Japanese firms developed joint ventures with British IFs, there was a subsequent take-over of these IFs by the more efficient Japanese so that 'In Britain there is a successful consumer electronics industry but it is owned largely by the Japanese' (Cawson, 1993: 118, emphasis in the original).
} 
technological gap between MNCs and IFs may be wide, indigenous quality standards low and the benefits of even limited informal involvement in the local sectoral organisations perceived to be small. This limited involvement is especially likely if the low labour cost advantage is expected to be short-lived, and the MNC is concerned to maximise returns over a short period.

There are additional factors influencing relations with IFs in industrialised countries. Firms may be anxious about competitive advantage and therefore unwilling to source locally for fear of the seepage of information to competitors. Certainly, with regard to hard technology, Balasubramanyam (1994: 86) concludes that MNCs 'are frequently shown to inhibit the development of local technological capabilities'. Firms may also be reluctant to participate in local sectoral associations or benchmarking for the same reasons. Even with FDI amongst the developed capitalist countries, investing MNCs can deliberately not establish links with IFs, as the Scottish example demonstrates (Ashcroft, 1997). It could be argued that Scotland, as with the former state socialist countries of CEE, is a national economy which as part of its integration into a 'triadicised' global economy has acquired a status of peripherality to the core European Union (EU) national states such as Germany. Not surprisingly then, and it must be said arising from research which has generated much debate, the same conclusion is made by Rainnie and Hardy (1996) in their analysis of FDI and the future of an economically restructured Poland. Accepting that some FDI will be successful, in terms of employment provision for example, they argue that the general trend is for limited branch plant investment such that 'Islands of relative success is a sea of peripherality will be the order of the day' (p.7) for Poland.

\section{The Applicability of Each Model}

There are four factors influencing the applicability of each model. The first is the strategy of the MNC. Clearly, if MNCs do not adopt innovative soft technologies themselves there is little potential for transfer and then diffusion to IFs. The second is the policies of host country and country of origin governments with their respective national institutional arrangements. The third is the policies and capabilities of IFs. The process is also affected by the nature of knowledge itself as it underpins any processes of transfer and diffusion within and between firms and across national boundaries.

\section{MNC Strategy}

There is extensive evidence and debate on the factors explaining internationalisation (Dunning, 1993; Casson, 1990). Evidence on the specific human resource policies of internationalising firms is more scarce (Ferner, 1997). At issue is how far MNCs adopt the labour utilisation policies and practices of their country of origin, or how far they develop a particular and standard type of international strategy for all their international activities or how 
far they adopt the policies of the host country. In a now classic article on senior management's attitude to developing and organising MNC enterprise around the world, Perlmutter (1995/1969) has labelled these possibilities 'ethnocentric', 'geocentric' and 'polycentric' respectively.

If MNCs follow their own national practices or adhere to international standards', how far do they concern themselves with the practices of the indigenous firms with which they deal? It may be hypothesised that this will depend upon several factors. First, the mode of internationalisation adopted. Firms with tightly coupled global production systems may be unwilling to commit themselves to sourcing locally, especially where economies of scale may result in lower production costs elsewhere. However, generally high commitment internationalisation strategies (joint ventures, wholly owned subsidiaries) will be associated with greater concern with management techniques both within the firm and amongst its associates. This will be especially so where the MNC is following a policy of vertical integration, especially upstream vertical integration. However, even with licensing arrangements MNCs may be expected to be concerned with management techniques, in view of the importance of maintaining reputation. In Scotland, MNCs tend to establish only limited backward integration into the local economy, preferring instead to operate international supplier networks (Ashcroft, 1997). Such networks often include other companies vertically integrated into the parent. Second, there is evidence of a 'country of origin' effect. It is suggested that US and Japanese firms transfer aspects of their national or standard international practices more frequently than UK or continental European MNCs (Ferner, 1997). Third, the degree of 'export orientation' of employment practices may also be expected to be linked to the level of integration within the firm: firms in which human resource policies are integrated into overall corporate strategies are more likely to concern themselves with the operation of human resource and other policies in their subsidiaries and associated firms. Finally, MNC policy and practice will be influenced by the host country. Some Governments, for example that of the UK, have actively pursued particular labour market strategies, usually, recently, encouraging greater flexibility.

In respect to MNC strategy, the Japanisation debate is instructive. The first wave of writing, eulogising lean production, claimed that the Japanese model was wholly transferable and, as a superior soft technology, could and should be transferred and adopted by all firms in all sectors in all countries (Womack, Jones and Roos, 1990). Counter research questioned the possibility of transfer, citing national institutional variations which limited the feasibility (see Industrial Relations Journal, 1988; Wilkinson and Oliver, 1990). As a result, it was suggested that 'full' or 'partial' Japanisation was possible by both investing Japanese MNC and IF as supplier or emulator depending upon host country 
institutional constraints. Later research then questioned the extent to which Japanese firms themselves engaged lean production in Japan, suggesting that it was sector specific and limited to the larger, core firms, with suppliers much like suppliers anywhere, having peripheral status with poor employment standards and working practices (Williams et al., 1992). Finally, more recent research has argued that the selectivity in the forms of Japanisation - full or partial - is not only related to the feasibility of its transfer across differing national institutional arrangements but reflects a deliberate core-periphery model previously identified as existing in Japan but now mapped onto the international economy by Japanese MNC FDI with the peripheral element more likely to be transferred overseas (Dedoussis and Littler, 1994). It would be unrealistic therefore to expect the innovative soft technology of lean production originally outlined in the first wave of research to be transferred and diffused overseas through FDI.

\section{Government Policies and National Business Systems}

The relationship between countries and firms is also important in shaping the nature and extent of FDI. The general point to be noted here is that, national states provide more than just physical economic infrastructure and political patronage for 'their' companies, a necessary social infrastructure is also provided without which MNCs would have to manufacture sets of organisationally specific practices and structures to provide company employees - managers and labour - with cohesion and understanding (Warhurst, Nickson and Shaw, 1998). We alluded earlier to country of origin effects on MNC employment policy.

The character of the host country is also important. At its most basic the political stability of the host country is an importance consideration for investing MNCs in CEE (Pye, 1998). Of more general consideration is what Whitley (1992) has called the 'national business system' of every country. Each national state has a distinctive patterning of institutions, for example legal frameworks, financial and banking regulations, training and education policies, industrial relations systems and familial arrangements. Firms are 'embedded' within configurations of these institutions. In order to secure resource support, these firms adopt the 'distinctive configuration of institutional arrangements' within which they are embedded (Stark and Nee, 1989: 9). The environment of firms thus constitutes identifiable and sustained social rules within positions, policies, programmes and procedures that are formed primarily within the national state and which are external and superior to the firm (Zucker, 1987).

Soft, as hard, technologies are the outcomes of these constructed social rules. Approaches to innovation, whether by MNCs or IFs are shaped by national business systems. For example, both the US and Danish Governments supported the development of wind turbine technology from the 1970s onwards. However the form of this support and the differences in technical education in these two countries resulted in different development trajectories, with small-scale, 
practical workshop-based development in Denmark and highly technical, largescale development in the US (Karnoe, 1995).

MNC policies then will likewise be affected by specific governmental policies characteristic of national business systems with their particular institutional arrangements. National government policy may be concerned specifically with MNCs, for example with levels of local content. National legislation may require specific employment practices (for example, on union recognition, employee consultation, redundancy, equal opportunities) with which MNCs as well as IFs are required to conform. In developed political cultures national government monitoring of MNC compliance may be expected to be closer than over indigenous firms, due to MNC political visibility. Second, the character of the national business system, especially the level of internal inter-firm integration, will affect knowledge transfer. Whitley (1992) has shown how financial institutions, property rights, state policies, labour market institutions as well as cultural factors affect the co-ordination and control of economic activity generally. To refer again to the diffusion of innovation, critical features include the role of the state and the network structure of interdependence between indigenous firms (Stark, 1996). MNCs are likely to be peripheral in highly integrated national business systems, such as Japan, and thus to exercise little influence on management techniques outside their own enterprises. This may reinforce the MNC's internal focus. Third, the labour market will affect the extent of transfer, most importantly the level of inter-firm labour mobility. High levels of inter-firm mobility, especially at the managerial level, will accelerate the transfer of new labour management practices. This level of mobility will, of course, depend partly on the policies of the MNCs themselves as well as upon the overall characteristics of the indigenous labour market. Finally, the overall institutional isomorphism between the country of origin and the host country will affect transfer: isomorphism - whether mimetic, coercive or normative - will accelerate transfer. In this respect, much has been made recently about the transformation of the Swedish and German national business systems towards the Anglo-American model driven by the needs of investing MNCs, including management consultancies in the case of Germany (see, for example, Thompson and Sederblad, 1994; Peppard and Fitzgerald, 1997). In CEE, in 1994, Ford threatened to cancel its investment in an automobile plant near Warsaw unless the Polish Government modified existing employment law to make the redundancy of workers easier (Butler 1994).

Governmental policies are not just national but also regional and, increasingly, supra national. Relevant supra national policies within Europe to be considered here include EU policies on local content as well as on employment issues such as employee consultation, trade union recognition and working time arrangements. 


\section{Indigenous Firms}

The third set of factors relates to the indigenous firms themselves and the MNCs' perceptions of the IFs. Two points are worth noting here: the ability and willingness of IFs to become part of an MNC production chain. Besides operating international supplier networks, part of the reasons that MNCs in Scotland tend not to use IFs is that although Scottish firms tend to invest significantly in research and development, they are less innovative in terms of organisation, process and product. A paradox also seems to occur in that although MNCs might be welcomed by the relevant inward investment agency in order to transfer soft technologies to IFs in Scotland, investing MNCs avoid these IFs because of supply side deficiencies, with the IFs failing to meet the more sophisticated standards of the MNCs (Ashcroft, 1997).

Auerbach and Stone (1991) point out that MNCs' 'leading edge' innovations occur with specialist managers, often aided by consultants. Smaller firms without such resources, such as typical IFs in peripheral states, are usually thus at the 'trailing edge'. Recent analysis of indigenous small firms by the TUC (1997) in the UK would support this argument. This report found that innovation and the adoption of new technologies and management techniques was closely related to size, with small firms worst on each count. Given the fact that Western IFs then might have difficulty engaging MNC innovation, Auerbach and Stone suggest that 'It would be particularly dangerous to assume that East European enterprises will quickly be able to make sense of and use managerial concepts developed to serve the needs of giant Western multinationals' (p.59).

Where IFs are willing and able to innovate they may seek linkages with MNCs, both for economic reasons and for prestige and organisational learning benefits. IFs secure access to international markets through MNCs which they would be unable to secure independently or through co-operation with indigenous firms. They may also secure the beneficial image of quality supplier. However, IFs may also recognise that the imbalance in dependence in the relations between themselves and the MNC is so large that the IF may be placed in an exploitable position. To return to the Japanese example, IF can find themselves locked into dependent supplier relationships with MNCs in which cost cutting measures required of the MNC are pushed down onto the suppliers. There are thus strategic benefits and costs for the IF. MNC calculations of the potential economic contribution of the IF, together with perceptions of the capabilities or potential capabilities - of IFs will foster or inhibit collaboration. However, MNCs face political pressure to favour IFs. The level of involvement of IFs in the MNCs' product markets and the level of employee skills will also influence the relationship. 


\section{On Knowledge}

Implicitly, Auerbach and Stone highlight the conceptual, as well as practical, difficulties involved in the transfer and diffusion of innovations. Shared understanding is not common though often assumed. At a basic level even words can evoke different meanings for different users. A fundamental word such as 'manager' in the English language has no Polish equivalent, and the same is true of 'marketing' (Jankowicz, 1994). It would thus be a mistake to strip out cultural differences in assessing the transferability of innovations. What difficulties exist in this respect for inter-firm transfer, as identified by Auerbach and Stone, exist also for inter-national transfer.

The transmission of innovations is thus affected by the nature of the knowledge being transferred. Codified and structured knowledge may be transferred relatively easily through formal mechanisms such as publications and through IT systems (Boisot, 1995). However, 'know how' can also be an intangible resource and research has suggested that as a form of tacit knowledge it is ranked by senior management as one of their companies' most important assets (Hall, 1992; 1993). This uncodified and unstructured knowledge is more difficult to transfer; such knowledge is more effectively transferred through experience, direct contacts and the circulation of employees. Soft technologies comprise a mix of structured and unstructured knowledge. Different societies rely more or less heavily on uncodified knowledge. For example, it has been argued that uncodified knowledge played a particularly important role in state socialist societies, since it was necessary to rely on such knowledge for bureaucratic protection as well as to provide the flexibility required to make an otherwise impossibly rigid society work in practice. MNCs operate largely on the basis of codified knowledge. The diffusion of soft technologies between MNCs and IFs in former state socialist societies will thus be affected by different approaches to management knowledge.

Moreover, Lam (1997) suggests that some knowledge is socially embedded and so context-bound. Such knowledge cannot be easily transferred by codification. Comprising not only its structures and practices but also relationships, an organisation's knowledge 'architecture' thus becomes problematic as much of it is tacit. As a consequence, there is created asymmetries of understanding in collaborative arrangements between MNCs and IFs. This problem exists not only for Western MNCs and CEE IFs but becomes amplified with increasing internationalisation generally. Moreover, not only is such knowledge bound by organisation-specific architecture, if Hall's $(1992 ; 1993)$ respondents are to be believed, it provides for competitive advantage for firms and so the desirability as well as feasibility of its transfer becomes an issue again.

It is here that a number of issues conflate with respect to IFs. IFs capacity to learn from MNCs might be constrained, firstly, by the nature of knowledge within MNCs and the importance of that knowledge to MNCs and, secondly, by 
the difficulties in the diffusion of that knowledge across firm and national boundaries. Given that IFs also tend to be 'trailing edge' rather than 'leading edge' in management techniques, it is understandable that investing MNCs 'play safe' in terms of existing mutual understandings and techniques and engage suppliers from their own country of origin, encouraging, as some Japanese MNCs do, these (now) MNC suppliers to also locate near to the new investment site in the host country (Crowther and Garrahan, 1988). ${ }^{5}$ IFs are thus further dislocated from sources of innovation.

\section{Conclusion}

The transfer and diffusion of innovative soft technologies by MNCs through FDI to host country IFs is regarded by academic and policy-makers alike throughout the world as both desirable and feasible. Yet, the transfer by MNCs across national boundaries and the diffusion therein by MNCs to IFs is not unproblematic in both respects. For academics and policy-makers in CEE there are clear lessons that can be learnt from the experience of non-CEE countries about the processes and effects MNC FDI in relation to IFs. Drawing on this experience, it is clear that MNCs may or may not engage this transfer, depending upon firm specific strategies. Specific host country government policies can facilitate or impede transfer. More generally, the national business systems within which MNCs originate or become embedded with FDI are another factor to be considered. It is also apparent that host country IFs may or may not be willing or able to be part of the process of diffusion. The strategies of MNCs, host and country of origin government polices characteristic of national business systems, and the capacities of IFs are all crucial considerations, and are so interactively. Although problematic and complex, examination of the relations between MNCs and IFs with regard to innovations in soft technologies is important though overlooked - much more research has been conducted on the transfer of 'hard' technology. Rectifying this oversight allows an examination of a number of important issues for CEE restructuring. Firstly, it provides a better assessment of the impact of MNCs upon open economies with different institutional structures, and in so doing contributes to understanding the interaction between internationalisation and institutional development. Secondly, it increases understanding of the processes of innovation diffusion and organisational learning both inter-firm and international. Thirdly, it provides for more informed policy making with regard to the role of MNCs as sources of innovation as well as employment generation in the countries of CEE. In this respect such analysis might help explain why Hungary and the Czech Republic attracted most FDI to 1997 and why

\footnotetext{
${ }^{5}$ These Japanese MNCs also often have equity shares in the supplier firms.
} 
substantially greater investment is now being made in Poland and Russia (Business Central Europe Online, 1999). Here, we have outlined some of the issues arising in the transfer and diffusion of soft technologies by MNCs to IFs within the developed capitalist states. What is now required is empirical analysis of this transfer and diffusion by investing MNCs in the former state socialist countries of CEE.

\section{References}

Archibugi, D. / Michie, J. (eds.) (1997): Technology, Globalisation and Economic Performance. Cambridge University Press / Cambridge.

Argyris, C. (1992): On Organisational Learning. Basil Blackwell / Oxford.

Ashcroft, B. (1997): External Investment and Economic Restructuring: the Scottish example. In: W.V. Wallace (ed.) Restructuring Economies: Poland and Scotland. Warsaw.

Auerbach, P. / Stone, M. (1991): Developing the New Capitalism in Eastern Europe - How the West Can Help. In: Long Range Planning. 24 (3). 58-65.

Balasubramanyam, V.N. (1994): The Transnational Corporation. In: Business History. 36 (2). 83-89.

Boisot, M. (1995): Information Space: a framework for learning in organisations. London.

Buckley, P.J. (1992): New Directions in International Business Research: Research Priorities for the 1990s. Aldershot.

Buckley, P.J. (1995): Foreign Direct Investment and Multinational Enterprises. London.

Bunt, K. (1992): Foreign direct investment intentions of major companies. In: Enterprise Development in Eastern Europe. No publication details.

Business Central Europe Online (1999): Foreign Direct Investment Flows. March.

Butler, R. 1994: Ford threatens Polish deal. In: The European. 20-26 May.18.

Casson, M. (ed.) (1990): Multinational Corporations. Aldershot.

Cawson, A. (1993): A High-Tech Industry: Consumer Electronics. In: R. Maidment / G. Thompson (eds.) Managing the UK. London.

Chen, E.K.Y. (1996): TNCs and technology transfer to developing countries. In: UNCTAD Division on Transnational Corporations and Investment Transnational Corporations and World Development. London.

Crowther, S. / Garrhan, P. (1988): Corporate power and the local economy. In: Industrial Relations Journal. 19. 51-59.

Darby, J. (ed.) (1997): Japan and the European Periphery. Basingstoke.

Dedoussis, V. / Littler, C. (1994): Understanding the Transfer of Japanese Management Practices. In: T. Elger / C. Smith (eds.) Global Japanisation. London.

Dunning, J.H. (1993): The Globalization of Business: The Challenge of the 1990s. London.

Dyker, D.A. (ed.) (1997): The Technology of Transition: Science and Technology Policy for Transition Countries. Budapest. 
Elger, T. / Smith, C. (eds) (1994): Global Japanization? The transnational transformation of the labour process. London.

Ellingstad, M. (1997): The Maquiladora Syndrome: Central European Prospects. In: EuropeAsia Studies. 49 (1) 56-71.

Ferner, A. (1997): Country of Origin Effects and HRM in Multi-national Companies. In: Human Resource Management Journal. 7 (1). 19-37.

Financial Times (1992): Multinationals switch focus of investment. 16 June. 12.

Friedman, A. (1990): Managerial Strategies, Activities, Techniques and Technology: Towards a Complex Theory of the Labour Process. In: D. Knights / H. Willmott (eds.) Labour Process Theory. London.

Frobel, F. / Heinrichs, J. / Kreye, O. (1980): The New International Division of Labour. Cambridge.

Hall, R. (1992): The strategic analysis of organisational resources. In: The Strategic Management Journal. 13.135-144.

Hall, R. (1993): A framework linking intangible resources and capabilities to sustain competitive advantage. In: The Strategic Management Journal. 14. 607-618.

Hertz, D.L. (1991): Developing Management Skills in Eastern Europe. In: Journal of European Business. 3 (1). 60-61.

Hoffman, K. (1986): Managing Technological Change in Developing Countries: The Impact and Policy Implications of Micro-electronics. London.

Hoffman, K. (1990): New Approaches to Best Practice Manufacturing: The Role of Transnational Corporations and Implications for Developing Countries. New York.

Industrial Relations Journal (1988) 19. Special Issue, Spring.

Jankowicz, A.D. (1994): The New Journey to Jerusalem: Mission and Meaning in the Managerial Crusade to Eastern Europe. In: Organization Studies. 15 (4). 479-507.

Karnoe, P. (1995): Institutional Interpretations and Explanations of Differences in American and Danish Approaches to Innovation. In: W.R. Scott / S. Christensen (eds.) The Institutional Construction of Organisations. London.

Kimura, Y. (1996): Japanese Direct Investment in the Peripheral Regions of Europe: An Overview. In: J. Darby (ed.) Japan and the European Periphery. London.

Kirkland, R.I. (1989): Who gains for the New Europe. In: Fortune. 18 December. 48-54.

Lam, A. (1997): Embedded Firms, Embedded Knowledge: Problems of Collaboration and Knowledge Transfer in Global Co-operative Ventures. Organization Studies. 18 (6). 973-96.

Liebenstein, H. (1978): General X-Efficiency Theory \& Economic Development. Oxford.

Macbeth, D.K. (1994): Partnership Sourcing: an integrated supply chain management approach. London.

Martin, R. (1998): Central and Eastern Europe and the International Economy: the limits to globalisation. In: Europe Asia Studies. 50 (1). 7-26.

Ohmae, K. (1995): Putting Global Logic First. In: Harvard Business Review. January/February. 119-25. 
Oliver, N. / Wilkinson, B. (1992): The Japanization of British Industry: New Developments in the 1990s. Oxford.

Pavitt, K. / Patel, P. (1988): The International Distribution and Determinants of Technological Activities. In: Oxford Review of Economic Policy. 4. 35-55.

Peppard, J. / Fitzgerald, D. (1997) The Transfer of Culturally-grounded Management Techniques: The Case of Business Process Reengineering in Germany. In: European Management Journal. 15 (4). 446-460.

Perlmutter, H.V. (1995/1969): The Tortuous Evolution of the Multinational Corporation. In: P.N. Pervez / S.B. Prasad (eds.) International Management: A Reader, London. / Columbia Journal of World Business. 4. 9-18.

Pye, R. (1998): Foreign Direct Investment in central Europe: Experiences of Major Western Investors. In: European Management Journal. 16 (4). 378-389.

Rainnie, A. / Hardy, J. (1996): Closer to the World? Restructuring of Polish State Owned Enterprises. Paper to the Globalisation of Production and the Regulation of Labour Conference. Warwick.

Rainnie, A. / Hardy, J. (1996): Restructuring Krakow: Desperately Seeking Capitalism. London.

Sadove, A.R. (1989): A Note on Industrial Restructuring in Socialist Countries - Changing Management's Psychological Outlook. In: Public Enterprises. 9 (2). 148-157.

Sako, M. (1992): Prices, Quality and Trust: inter-firm relations in Britain and Japan. Cambridge.

Senge, P.M. (1990): The Fifth Discipline: The Art and Practice of the Learning Organisation. New York.

Stark, D. (1996): Recombitant Property in East European Capitalism. In: American Journal of Sociology. 101 (4). 993-1027.

Stark, D. / Nee, V. (1989): Toward an Institutional Analysis of State Socialism. In: V. Nee / D. Stark (eds.) Remaking the Economic Institutions of Socialism. Stanford.

Taylor, B. / Elger, T. / Fairbrother, P. (1994): Transplants and Emulators: The Fate of the Japanese Model in British Electronics. In: T. Elger / C. Smith (eds.) Global Japanization?. London.

Thompson, P. / Sederblad, P. (1994): The Swedish Model of Work Organisation in Transition. In: T. Elger / C. Smith (eds.) Global Japanisation?. London.

Trade Union Congress (1997): The Small Firms Myths. Economic and Social Affairs Department. London.

Warhurst, C. / Nickson, D. / Shaw, E. (1998): 'A Future for Globalization? International Business Organization in the Next Century. In: T. Scandura / M.G. Serapio (eds.) Research in International Business and International Relations 7. Stamford.

Whitley, R. (ed.) (1992): European Business Systems: Firms and Markets in their National Contexts. London.

Wilkinson, B. / Oliver, N. (1990): Obstacles to Japanisation: The Case of Ford UK. In: Employee Relations. 12 (1). 17-21. 
Williams, K. / Haslam, C. / Williams, J. / Cutler, T. / Adcroft, A. / Sukhdev, J. (1992): Against Lean Production. In: Economy and Society. 21 (2). 321-54.

Womack, J.P. / Jones, D.T. / Roos, D. (1990): The Machine that Changed the World. New York.

Zucker, L.G. (1987): Institutional Theories of Organisation. In: American Review of Sociology. 13. 443-464. 